\section{Physical Society's Exhibition}

THe twenty-sixth annual exhibition of scientific instruments and apparatus, arranged by the Physical Society, will be held on January 7, at the Imperial College of Science and Technology, Imperial Institute Road, South Kensington, S.W.7. Manufacturers of scientific instruments will be exhibiting their products in the Trade Section. The Research and Experimental Section will contain contributions from research laboratories, and there will be a special sub-section devoted to experiments of educational interest. In addition, the work submitted for the Craftsmanship and Draughtsmanship Competition by apprentices and learners will be on view. Discourses will be delivered on two days at 7.45 p.m. as follows: January 7, R. A. Bull, "Some Instruments used in recording Sound on Film"; January 8, R. W. Paul, "Electrical Measurements before 1886". Admission to the exhibition is by ticket only. Members of institutions and scientific societies may obtain tickets from their secretaries; tickets may also be obtained direct from the Exhibition Secretary, 1, Lowther Gardens, Exhibition Road, S.W.7.

\section{American Association for the Advancement of Science}

THE American Association for the Advancement of Science will hold its ninety-seventh meeting at St. Louis, commencing on December 30. On the first evening, the retiring president, Dr. Edward L. Thorndike, will deliver an address entitled: "Science and Values". Among the special lectures are J. B. Taylor, "The Electric Eye and the Human Eye" (Sigma xi Address); Prof. J. E. Woodridge, "The Claims of Science" (first of series of annual lectures to be arranged by the United Chapters of Phi Beta Kappa) ; Dr. H. G. Moulton, "The Scientific Method in the Investigation of Economic Problems"; Dr. B. A. Houssay, "Hypophysis and Metabolism"; Dr. Karl F. Meyer, "Plague, Past and Present"; Dr. E. H. Barbour, "The Proboscidea of the Plains" ; Prof. F. Slocum, "The Changing Picture of the Universe" ; Dr. V. O. Knudsen, "The Absorption of Sound in Gases"; Dr. V. Bush, "Mechanical Analysis" (Josiah Willard Gibbs Lecture), A meeting will also be arranged between the secretaries of sections and affiliated societies and representatives of the Press to discuss the broader principles or the technique of the popular presentation of science. Further information can be obtained from the Permanent Secretary, Dr. Henry B. Ward, Smith. sonian Institution Building, Washington, D.C.

\section{Announcements}

WE much regret to announce the death, which occurred on December 16 at the age of eighty-one years, of Sir Richard Glazebrook, K.C.B., K.C.V.O., F.R.S., from 1889 until 1919 director of the National Physical Laboratory, and from 1908 until 1933 chairman of the Aeronautical Research Committee; also of Mr. P. C. Gilchrist, F.R.S., who was associated with the late Mr. S. G. Thomas in the introduction of the basic Bessemer process for the production of iron, on December 15, aged eighty-three years.
IT is announced that the King has been pleased to appoint Mr. Edgar John Forsdyke, keeper of the Department of Greek and Roman Antiquities at the British Museum, to be director and principal librarian of the Museum, in succession to Sir George Hill, who will retire in Midsummer, 1936.

Dr. G. A. Young, chief geologist of the Canadian Geological Survey, has been elected president of the Royal Society of Canada in succession to the late Dr. Reginald W. Brock.

Prof. Otro Lehmans, director of the Museum at Altona, has been awarded the Goethe Medal for Science and Art.

A MEDallion has recently been affixed to the house at Confolens in the Department of Charente, in which the late Dr. Emile Roux, the director of the Pasteur Institute of Paris, was born.

Ix has been arranged for a number of the official lectures which are being given in connexion with the Exhibition of Chinese Art at Burlington House, to be published in the Journal of the Royal Society of Arts. The first of these, "The Chinese Exhibition", by Sir Percival David, has already appeared, and Miss Helen Fernald's lecture on "The T'ang 'T'ai Tsung Horses" is being published on December 20. Copies may be obtained from the Secretary, Royal Society of Arts, John Street, Adelphi, W.C.2, price 1s. each.

A SPECral section of the Illuminating Engineering Society to be devoted to photometry and allied subjects is now being formed. The honorary secretary is Mr. K. F. Sawyer, of the Gas Light and Coke Company, Watson House, Nine Elms Lane, London, S.W.8. Arrangements have been made for the opening meeting to take place at the Westminster Technical Institute, Vincent Square, London, S.W.1, at 6.30 p.m. on January 28. An introductory address, dealing with certain outstanding problems in photometry, will be delivered by Dr. J. W. T. Walsh.

Erratum.-In the communications by G. Wald entitled "Pigments of the Bull Frog Retina" (NATURE, Nov. 23, p. 832) and "The Visual Purple System in Marine Fishes" (NATURE, Dec. 7, p. 913), the ordinates of the graphs should read "Extinction $\left(\log I_{0} / I\right)$ " instead of "Extinction (109 $I_{0} / I$ )" as printed.

Applicatrons are invited for the following appointments, on or before the dates mentioned :

A John William Hughes professor of civil engineering in the University of Liverpool-The Registrar (Feb. 10).

A principal of the Leathersellers' Technical College -The Clerk to the Governors, Leatherseller's' Hall, St. Helen's Place, London, E.C.3.

An engineer to the Government of Nigeria-The Crown Agents for the Colonies, 4, Millbank, London, S.W.1. 